\title{
Banking Service Quality Analysis in Facing Challenges and Opportunities for Business Development
}

\author{
Edhi Asmirantho \\ Management, Pakuan University \\ Bagor, Indonesia \\ rantho.bs@gmail.com
}

\author{
Rorim Panday \\ Management, Bhayangkara Jaya University \\ Jakarta, Indonesia \\ indripan@gmail.com
}

\begin{abstract}
Banking business competition is so tight, in terms of offering banking products. In the competition, there is always many challenges and an opportunities. Banking business included in service operations, thus each bank trying to service its services to provide satisfaction to its customers and to attract new customers, not least for ABC Bank. Research on the quality of service at ABC Bank, applying SERVQUAL introduced by Parasuraman, by making adjustments to the instrument. To sharpen the analysis used the t-test and Important Performance Analysis (IPA). Respondents in this study were 370 people, which are customers of the bank. The results of this study showed, from 24 variables of service quality, there are 12 variables have not meet customer expectations, 3 variables already meets the expectations and 9 variables are in accordance with customer expectations. In addition, from the IPA, there are 6 variables showed as high priority, 8 variables as retained, 7 variables with low priority and 3 variables that have been excessive. Conclusions from the analysis of the two methods produce indicators that have not met the expectations there are 13 indicators, which has been as expected there were 8 indicators and which meet the expectations there were 3 indicators. Thus the Bank management should improve the 13 indicators of service quality, maintain eight indicators that have been as expected and also maintains three indicators that meet quality expectations.
\end{abstract}

Keywords: Service Quality, t-test, important performance analysis.

\section{INTRODUCTION}

The service sector is considered to be the most dynamic and innovative component of a functioning market economy, becoming the last decades the main "engine of growth" of developed economies. One of the service sector is the Bank. Competition between banks in Indonesia is very high, with a lot of banks in Indonesia.

With existence of financial liberalization has led to intense competitive pressures and private banks dealing in retail banking are consequently directing their strategies towards increasing service quality level which fosters customer satisfaction and loyalty through improved service quality [1].

Private Banks dealing in retail banking Industry is consequently put into lot of pressures due towards increase in global competition. Various strategies are formulated to retain the customer and the key of it is to increase the service quality level. Typically, customers perceive very little difference in the banking products offered by private banks dealing in services as any new offering is quickly matched by competitors. Parasuraman [2] and Zeithaml [3] noted that the key strategy for the success and survival of any business institution is the deliverance of quality services to customers in facing those challenges and opportunities for business development.

Undoubtedly, in the beginning of this century customer satisfaction defines very clearly the meaning and significance of today's real economic activities. In this sense, extensive production and consumption of products and services is not the sole purpose of economic activities today, the main purpose of companies. From a certain perspective, the main purpose of companies is to "sell" products or services, respectively to produce and deliver those products or services that meet in a very high degree requirements and needs of consumers or users [4]. Thus, the importance of customer satisfaction, in general, consists in recognizing the mode and the way in which organizations generate and create "pleasure" so in the consumers of products or services and among suppliers of such services or products.

Numerous studies have shown the importance of customer satisfaction for these organizations by highlighting the link between customer satisfaction and financial results, customer satisfaction and maintaining or attracting customers. Concerning the role of customer satisfaction, this can play many roles for an organization, whether private or public. As an overview and synthesis, customer satisfaction can affect many organizational processes, being used as a tool in many areas posed by an organization. The way to deliver customer satisfaction is to provide quality service. This paper will discuss how to evaluate the quality of service at $\mathrm{ABC}$ private bank in Jakarta in facing the challenges and opportunities, use the servqual principles and diagrams Important Performance Analysis.

\section{REVIEW OF LITERATURE}

Service is part of the operating system. Input of service may consist of buildings, spaces, equipment, decorations, and 
other physical facilities that support. Another part of the input are employees and managers, machineries, equipments, and abilities. All of the physical form called tangibles. Managers and employees provide services in a way that is timely and fulfill what was promised, done quickly responsive, reliable, do not give rise to doubts and done with empathy, resulting in the output quality of service and giving effect to customer satisfaction. All of that are the operating system services of organizations including banks. This operating system is also as system production of services. This bank operating system must be evaluated periodically, so that the bank can always provide service excellent to provide customer satisfaction excellence. In the end quality of service being the foremost.

There is still no consensus on a definition for quality. For this paper, that of Parasuraman [2] is adopted: "Service quality as perceived by the customer is the degree and direction of discrepancy between customer service perceptions and expectations"[2]. It is this gap between perceptions and expectations that underpins the formulation of SERVQUAL, the service quality measuring instrument of Parasuraman [5] and its subsequent refinements $(1990,1993,1994)$. The instrument is based on the idea of the disconfirmation model, in other words on the comparison of customers' expectations with their experiences from the service, corresponding defined by [2]. Usually, the five dimensions of the instrument are described through the use of 22 attributes an "respondents are asked to state (on a five-point scale from "Strongly disagree" to "Strongly agree") what they expected from the service and how they perceived the service." Since its formulation, SERVQUAL has been used in a variety of service industries and countries. Although in development had criticism of Cronin and Taylor [6], Avkiran [7], in which they criticize about expectation measurement, the effectiveness of the instrument in measurement and the complex content of using negative sentences and time-consuming.

In the development dimension of the service quality that was developed by Parasuraman [2] into five dimensions: tangible, reliability, responsiveness, assurance and empathy. Tangibility, including physical facilities, equipment, personnel and means of communication. Reliability, ie the ability of the company to deliver the promised services in a timely and satisfactory. Responsiveness, namely the ability of the staff to help customers and provide services to respond. Assurance, covering ability, courtesy and trustworthiness that of the staff, free from danger, risk or doubt. And last Empathy, include the ease of having good communication and understanding the needs of customers.

Customer expectations of service quality shows how important a quality of service. Thus the perception of service quality and service quality expectations means also the perception of the performance and the level of importance of service quality. So as to analyze further on SERVQUAL can be forwarded to the Important-Performance Analysis (IPA).
Importance Performance Analysis (IPA) is an analytical approach proposed by Martilla and James[8], based on the expected performance by measuring the perception of the quality and level of importance [9,10,11]; and it is generally used to provide guidance in making strategic marketing decisions. Some researchers use it as the transport [12], banks [13], college [14], hospitality [15] and tourism [16]. This method has proved to be relatively easy to administer and interpret, resulting in widespread use among researchers and managers in various fields, and a way to promote the development of effective operation of the program, as it facilitates the interpretation of data and improve the usefulness in making strategic decisions [10,11, 17, 18, 19]. IPA consists of a pair of coordinate axes where 'importance' (y-axis) and performance (x-axis) of the elements involved in the service compared (see Fig. 1).

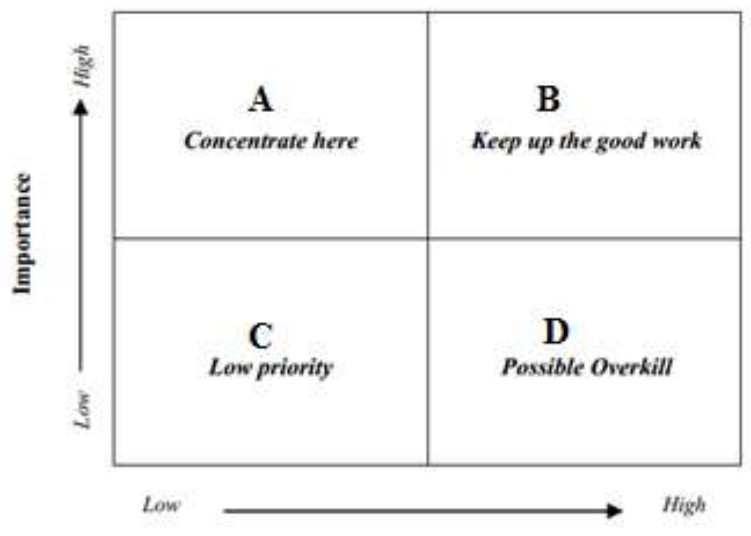

Fig 1. Diagram Importance- Performance

Each quadrant-level combination of importance and performance provided by the customer / user specified in the service element and the average value of each level of importance and performance attributes is the starting point of this IPA matrix [8, 20, 21,11, 22, 14, 23, 19]. Each quadrant shows the different strategies. The four quadrants in the analysis of performance Important- marked as [8]:

- A. Main Priority - an important level is highperformance level is low: It is the main priority;

- B. Surviving - with high-level importance of good work, showing high performance that must be maintained

- C. Low priority - low interest, low performance: minor weakness and do not require additional effort;

- D. Possible excessive - high performance low- interest: indicates that the business resources committed to this attribute will be redundant and should be placed elsewhere.

Research related to the services quality of banking and application of Important Performance Analysis (IPA) in the review by researchers are as follows: 
TABLE 1. LIST OF RELATED RESEARCHES

\begin{tabular}{|c|c|c|c|c|}
\hline No & Researcher & Titles & Variables & Method \\
\hline 1 & $\begin{array}{l}\text { Krisna } \text { Mahendraswara } \\
\text { [24] }\end{array}$ & $\begin{array}{l}\text { Studi Terhadap Kualitas } \\
\text { Pelayanan di Hotel Grand } \\
\text { Candi Semarang }\end{array}$ & SERVQUAL & $\begin{array}{l}\text { Important Performance } \\
\text { Analysis }\end{array}$ \\
\hline 2 & $\begin{array}{l}\text { Asif Akhtar \& Dr. Asma } \\
\text { Zaheer [25] }\end{array}$ & $\begin{array}{l}\text { Service Quality } \\
\text { Dimensions of Islamic } \\
\text { Banks: A Scale } \\
\text { Development Approach in } \\
\text { the Gulf countries }\end{array}$ & SERVQUAL & $\begin{array}{l}\text { Principal Component } \\
\text { Analysis (PCA) and } \\
\text { Confirmatory Factor } \\
\text { Analysis (CFA) to } \\
\text { validate the scale. } \\
\text { Independent sample T } \\
\text { test and One Way } \\
\text { ANOVA are used to } \\
\text { validate the hypotheses. }\end{array}$ \\
\hline 3 & $\begin{array}{l}\text { Herni Justiana Astuti } \\
{[26]}\end{array}$ & $\begin{array}{lr}\text { Analisis } & \text { Kepuasan } \\
\text { Konsumen (SERVQUAL } \\
\text { Model dan Important } \\
\text { Performance } \\
\begin{array}{l}\text { Model) } \\
\text { Analysis }\end{array}\end{array}$ & SERVQUAL & $\begin{array}{l}\text { Important Performance } \\
\text { Analysis }\end{array}$ \\
\hline 4 & 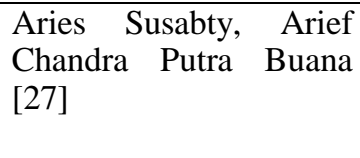 & $\begin{array}{lr}\text { Atribut-Atribut } & \text { yang } \\
\text { Menjadi Prioritas } & \text { Untuk } \\
\text { Peningkatan } & \text { Kualitas } \\
\text { Layanan } & \end{array}$ & SERVQUAL & $\begin{array}{l}\text { Important Performance } \\
\text { Analysis }\end{array}$ \\
\hline 5 & $\begin{array}{l}\text { Jannatul Mawa Nupur } \\
\text { [28] }\end{array}$ & $\begin{array}{l}\text { E-Banking and Customers' } \\
\text { Satisfaction in Bangladesh: } \\
\text { An Analysis }\end{array}$ & $\begin{array}{c}\text { SERVQUAL } \\
\text { Customers' Satisfaction }\end{array}$ & $\begin{array}{l}\text { Multiple regression } \\
\text { analysis }\end{array}$ \\
\hline 6 & $\begin{array}{l}\text { Mohamad Idham Md } \\
\text { Razak et. al [29] }\end{array}$ & $\begin{array}{l}\text { Adaptive of SERVQUAL } \\
\text { Model in } \text { Measuring } \\
\text { Customer } \\
\text { towards Service Quality } \\
\text { Provided by Bank Islam } \\
\text { Malaysia Berhad (BIMB) } \\
\text { in Malaysia }\end{array}$ & $\begin{array}{c}\text { SERVQUAL } \\
\text { Customer Satisfaction }\end{array}$ & $\begin{array}{l}\text { Multiple regression } \\
\text { analysis }\end{array}$ \\
\hline 7 & Bente Corneliu [4] & $\begin{array}{l}\text { Concepts of Service } \\
\text { Quality Measurement in } \\
\text { Banks (Romania) }\end{array}$ & SERVQUAL & Gap analysis \\
\hline 8 & $\begin{array}{l}\text { E. O. Oyetunji, B. B. } \\
\text { Baguri and A. E. Otis } \\
{[30]}\end{array}$ & $\begin{array}{llr}\text { Comparison } & \text { of } & \text { Service } \\
\text { Quality } & \text { of } & \text { Two } \\
\text { Commercial } & \text { Banks in } \\
\text { Upper East } & \text { Region of } \\
\text { Ghana } & & \end{array}$ & SERVQUAL & $\begin{array}{c}\text { Gap analysis, } \\
\text { descriptive analysis }\end{array}$ \\
\hline 9 & Aymn Sulieman [31] & $\begin{array}{l}\text { Basic Dimensions of the } \\
\text { (SERVQUAL Model) and } \\
\text { its Impact on the Level of } \\
\text { Customer Satisfaction: an } \\
\text { emperical study of the } \\
\text { Housing Bank in Karak, } \\
\text { Jordan }\end{array}$ & $\begin{array}{c}\text { SERVQUAL, } \\
\text { customer satisfaction }\end{array}$ & $\begin{array}{l}\text { Descriptive, Multiple } \\
\text { regression }\end{array}$ \\
\hline 10 & Ramón A. Carrasco [32] & $\begin{array}{l}\text { A model for the integration } \\
\text { of e-financial services } \\
\text { questionnaires with } \\
\text { SERVQUAL scales under } \\
\text { fuzzy linguistic modeling }\end{array}$ & SERVQUAL & Fuzzy linguistic model \\
\hline
\end{tabular}




\begin{tabular}{|c|c|c|c|c|}
\hline 11 & $\begin{array}{l}\text { Jelena Titko, Natalja } \\
\text { Lace [33] }\end{array}$ & 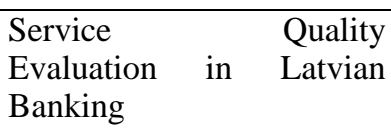 & SERVQUAL & SERVPERF \\
\hline 12 & Ghalib Sanjuq [34] & $\begin{array}{l}\text { The Impact of Service } \\
\text { Quality Delivery on } \\
\text { Customer Satisfaction in } \\
\text { the Banking Sector in } \\
\text { Riyadh, Saudi Arabia }\end{array}$ & $\begin{array}{c}\text { SERVQUAL, } \\
\text { Customer satisfaction }\end{array}$ & Regression analysis \\
\hline 13 & $\begin{array}{l}\text { K. Ravichandran et al } \\
{[1]}\end{array}$ & 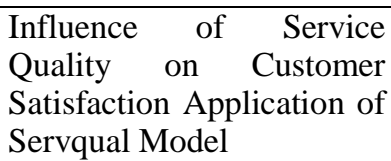 & $\begin{array}{c}\text { SERVQUAL, } \\
\text { Customer satisfaction }\end{array}$ & Regression analysis \\
\hline 14 & Mei Mei Lau et al.[35] & $\begin{array}{l}\text { Measuring Service Quality } \\
\text { in the Banking Industry: A } \\
\text { Hong Kong Based Study }\end{array}$ & $\begin{array}{c}\text { SERVQUAL, } \\
\text { customer satisfaction and } \\
\text { customer loyalty }\end{array}$ & $\begin{array}{l}\text { Descriptive analysis } \\
\text { Factor analysis SEM }\end{array}$ \\
\hline 15 & $\begin{array}{l}\text { Soleyman Iranzadeh, } \\
\text { and Farzam } \\
\text { Chakherlouy [36] }\end{array}$ & $\begin{array}{l}\text { Service Quality } \\
\text { Dimensions in the Banking } \\
\text { Industry and Its Effect on } \\
\text { Customer Satisfaction } \\
\text { (Case Study Iran) }\end{array}$ & $\begin{array}{c}\text { SERVQUAL, } \\
\text { customer satisfaction }\end{array}$ & One-Sample Test \\
\hline 16 & $\begin{array}{l}\text { Niveen El Saghier, } \\
\text { Demyana Nathan [37] }\end{array}$ & \begin{tabular}{lr} 
Service & Quality \\
Dimensions & and \\
Customers' Satisfactions \\
\multicolumn{2}{l}{ of Banks in Egyp }
\end{tabular} & $\begin{array}{c}\text { SERVQUAL, } \\
\text { customer satisfaction }\end{array}$ & Regression analysis \\
\hline 17 & Najat Abdullrahim [38] & $\begin{array}{l}\text { Service Quality of English } \\
\text { Islamic Banks }\end{array}$ & SERVQUAL & $\begin{array}{lr}\text { EIBSQ,English } & \text { Islamic } \\
\text { Banking } & \text { Service } \\
\text { Quality tool. } & \text { Factor } \\
\text { analysis } & \end{array}$ \\
\hline
\end{tabular}

Of 17 relevant studies that were examined, the study conducted by researchers is different in its data processing and analysis methods. Researchers combined the results of t-test analysis with the results of the analysis of the IPA..

\section{METHODOLOGY}

This study was a quantitative study using SERVQUAL concept of Parasuraman by using a modified questionnaire, comprising 24 indicators, adapted to the circumstances Bank studied. The questionnaire was made of two kinds, namely on the level of interest of the expected quality of service and quality of existing services. Assessment of the expected level of service quality using the gradation as Strongly disagree (1) to Strongly agree (5). And assessment of service quality using the gradation Poor (1) to Very well (5). Respondents are ABC Bank customer randomly assigned as many as 370 respondents. To test the feasibility of using the results of the questionnaire, validity and reliability of the Pearson correlation coefficient and Cronbach coefficient conducted. To see how big the difference between the expected value and quality of service, then the t-test performed. To see further service quality strategies used cartesian diagram of Important Performance Analysis.

\section{RESULT AND DISCUSSION}

From the data collected as many as 370 respondents, data tabulated, by using SPSS Ver. 11.5, then calculated the value of validity for each indicator of the service quality, and reliability value for each dimension of service quality. The results of validity and reliability presented in Table 2 . For each indicator of service quality dimensions, showed the value of the Pearson correlation significant at the 0.01 level. And the value of reliability for each dimension of service quality, showed the value greater than 0.6. Thus, the data obtained are valid and reliable.

TABLE 2. VALIDITY AND RELIABILITY RESULTS

\begin{tabular}{|l|r|l|r|}
\hline \multicolumn{4}{|c|}{ Tangibles } \\
\hline \multicolumn{3}{|c|}{ Perceived quality } & \multicolumn{2}{c|}{ Expectation quality } \\
\hline & $\begin{array}{c}\text { Pearson } \\
\text { Correlation }\end{array}$ & $\begin{array}{c}\text { Pearson } \\
\text { Correlation }\end{array}$ \\
\hline X1 &, $685(* *)$ & Y1 &, $720(* *)$ \\
\hline X2 &, $630(* *)$ & Y2 &, $729(* *)$ \\
\hline X3 &, $831(* *)$ & Y3 &, $668(* *)$ \\
\hline X4 &, $749(* *)$ & Y4 &, $796(* *)$ \\
\hline X5 &, $826(* *)$ & Y5 &, $739(* *)$ \\
\hline
\end{tabular}




\begin{tabular}{|c|c|c|c|}
\hline Alpha = & 8014 & Alpha $=$ &, 7787 \\
\hline \multicolumn{4}{|c|}{ Reliability } \\
\hline \multicolumn{2}{|c|}{ Perceived quality } & \multicolumn{2}{|c|}{ Expectation quality } \\
\hline & $\begin{array}{c}\text { Pearson } \\
\text { Correlatio } \\
n\end{array}$ & & $\begin{array}{l}\text { Pearson } \\
\text { Correlation }\end{array}$ \\
\hline $\mathrm{X} 6$ &, $888(* *)$ & Y6 &, $892(* *)$ \\
\hline $\mathrm{X} 7$ & ,894(**) & $\mathrm{Y7}$ & ,915(**) \\
\hline $\mathrm{X} 8$ & ,896(**) & Y8 & ,907(**) \\
\hline $\mathrm{X} 9$ & ,735(**) & Y9 & ,739(**) \\
\hline $\mathrm{X} 10$ &, $841(* *)$ & Y10 & ,906(**) \\
\hline Alpha = & ,9088 & Alpha $=$ & ,9230 \\
\hline \multicolumn{4}{|c|}{ Responsiveness } \\
\hline \multicolumn{2}{|c|}{ Perceived quality } & \multicolumn{2}{|c|}{ Expectation quality } \\
\hline & $\begin{array}{c}\text { Pearson } \\
\text { Correlatio } \\
\mathrm{n}\end{array}$ & & $\begin{array}{c}\text { Pearson } \\
\text { Correlation }\end{array}$ \\
\hline $\mathrm{X} 11$ &, $815(* *)$ & Y11 &, $918(* *)$ \\
\hline $\mathrm{X} 12$ &, $826(* *)$ & $\mathrm{Y} 12$ &, $879(* *)$ \\
\hline $\mathrm{X} 13$ &, $820(* *)$ & Y13 &, $840(* *)$ \\
\hline $\mathrm{X} 14$ &, $773(* *)$ & Y14 & ,886(**) \\
\hline Alpha $=$ & 8217 & Alpha $=$ & ,9028 \\
\hline \multicolumn{4}{|c|}{ Assurance } \\
\hline \multicolumn{2}{|c|}{ Perceived quality } & \multicolumn{2}{|c|}{ Expectation quality } \\
\hline & $\begin{array}{c}\text { Pearson } \\
\text { Correlatio } \\
n\end{array}$ & & $\begin{array}{c}\text { Pearson } \\
\text { Correlation }\end{array}$ \\
\hline
\end{tabular}

\begin{tabular}{|c|c|c|c|}
\hline $\mathrm{X} 15$ &, $777(* *)$ & Y15 &, $880(* *)$ \\
\hline $\mathrm{X} 16$ & ,762(**) & Y16 &, $823(* *)$ \\
\hline $\mathrm{X} 17$ &, $869(* *)$ & Y17 & ,929(**) \\
\hline $\mathrm{X} 18$ &, $842(* *)$ & Y18 & ,893(**) \\
\hline $\mathrm{X} 19$ &, $869(* *)$ & Y19 &, $880(* *)$ \\
\hline $\mathrm{X} 20$ &, $872(* *)$ & Y20 & ,876(**) \\
\hline $\mathrm{X} 21$ &, $846(* *)$ & Y21 &, $888(* *)$ \\
\hline Alpha = & ,9258 & Alpha = & ,9519 \\
\hline \multicolumn{4}{|c|}{ Emphaty } \\
\hline \multicolumn{2}{|c|}{ Perceived quality } & \multicolumn{2}{|c|}{ Expectation quality } \\
\hline & $\begin{array}{c}\text { Pearson } \\
\text { Correlation }\end{array}$ & & $\begin{array}{c}\text { Pearson } \\
\text { Correlation }\end{array}$ \\
\hline $\mathrm{X} 22$ &, $897(* *)$ & Y22 & ,935(**) \\
\hline $\mathrm{X} 23$ &, $889(* *)$ & Y23 & ,912(**) \\
\hline $\mathrm{X} 24$ &, $819(* *)$ & $\mathrm{Y} 24$ &, $877(* *)$ \\
\hline \multicolumn{2}{|c|}{ Alpha $=, 8365$} & \multicolumn{2}{|c|}{ Alpha $=, 9019$} \\
\hline
\end{tabular}

Further t-test, with the results shown in Table-3. From the results of $\mathrm{t}$ - test produced 12 indicators have not met the expectations of service quality where the expected value were greater than the quality of existing services and the difference was significant, 3 indicators already meet the expectation of quality of service in which the value of quality of service were greater than the value of the service quality expectations and significant difference, and 9 indicators were in accordance with the expectations of service quality in which the difference between the expected value and service quality difference is not significant.

TABLE 3. PAIRED SAMPLES STATISTICS TEST

\begin{tabular}{|l|l|r|r|l|r|r|r|r|c|}
\hline \multicolumn{2}{|c|}{ Indicators } & Mean & $\begin{array}{c}\text { Std. } \\
\text { Deviation }\end{array}$ & & Mean & $\begin{array}{c}\text { Std. } \\
\text { Deviation }\end{array}$ & $\mathrm{t}$ & $\begin{array}{c}\text { Sig. (2- } \\
\text { tailed) }\end{array}$ & Meaning \\
\hline Pair 1 & $\mathrm{X} 1$ & 3,48 &, 875 & $\mathrm{Y} 1$ & 4,06 &, 846 & $-10,275$ &, 000 & not fulfilled \\
\hline Pair 2 & $\mathrm{X} 2$ & 3,61 &, 780 & $\mathrm{Y} 2$ & 3,95 &, 918 & $-6,236$ &, 000 & not fulfilled \\
\hline Pair 3 & $\mathrm{X} 3$ & 4,04 &, 869 & $\mathrm{Y} 3$ & 3,73 &, 913 & 5,301 &, 000 & already meet \\
\hline Pair 4 & $\mathrm{X} 4$ & 3,86 &, 874 & $\mathrm{Y} 4$ & 3,67 &, 825 & 3,424 &, 001 & already meet \\
\hline Pair 5 & $\mathrm{X} 5$ & 3,81 &, 989 & $\mathrm{Y} 5$ & 3,50 &, 955 & 5,005 &, 000 & already meet \\
\hline Pair 6 & $\mathrm{X} 6$ & 4,01 &, 808 & $\mathrm{Y} 6$ & 4,02 &, 787 &,- 261 &, 794 & is in accordance \\
\hline Pair 7 & $\mathrm{X} 7$ & 4,13 &, 783 & $\mathrm{Y} 7$ & 4,15 &, 778 &,- 517 &, 606 & is in accordance \\
\hline Pair 8 & $\mathrm{X} 8$ & 3,99 &, 849 & $\mathrm{Y} 8$ & 4,03 &, 745 & $-1,110$ &, 268 & is in accordance \\
\hline Pair 9 & $\mathrm{X} 9$ & 3,85 &, 868 & $\mathrm{Y} 9$ & 3,93 &, 802 & $-1,962$ &, 050 & not fulfilled \\
\hline Pair 10 & $\mathrm{X} 10$ & 4,01 &, 811 & $\mathrm{Y} 10$ & 4,04 &, 753 &,- 764 &, 445 & is in accordance \\
\hline Pair 11 & $\mathrm{X} 11$ & 3,99 &, 873 & $\mathrm{Y} 11$ & 4,20 &, 763 & $-3,499$ &, 001 & not fulfilled \\
\hline Pair 12 & $\mathrm{X} 12$ & 3,78 &, 850 & $\mathrm{Y} 12$ & 4,03 &, 782 & $-4,419$ &, 000 & not fulfilled \\
\hline Pair 13 & $\mathrm{X} 13$ & 4,03 &, 732 & $\mathrm{Y} 13$ & 4,12 &, 810 & $-1,699$ &, 090 & is in accordance \\
\hline Pair 14 & $\mathrm{X} 14$ & 3,98 &, 788 & $\mathrm{Y} 14$ & 3,92 &, 803 & 1,028 &, 304 & is in accordance \\
\hline Pair 15 & $\mathrm{X} 15$ & 3,89 &, 792 & $\mathrm{Y} 15$ & 3,94 &, 817 &,- 894 &, 372 & is in accordance \\
\hline Pair 16 & $\mathrm{X} 16$ & 3,74 &, 819 & $\mathrm{Y} 16$ & 4,01 &, 798 & $-5,456$ &, 000 & not fulfilled \\
\hline
\end{tabular}




\begin{tabular}{|l|l|r|r|l|r|r|r|r|c|}
\hline Pair 17 & X17 & 3,87 &, 868 & Y17 & 4,04 &, 741 & $-3,352$ &, 001 & not fulfilled \\
\hline Pair 18 & X18 & 3,87 &, 876 & Y18 & 4,11 &, 742 & $-4,514$ &, 000 & not fulfilled \\
\hline Pair 19 & X19 & 3,83 &, 808 & Y19 & 3,88 &, 826 & $-1,012$ &, 312 & is in accordance \\
\hline Pair 20 & X20 & 3,73 &, 817 & Y20 & 3,95 &, 792 & $-3,822$ &, 000 & not fulfilled \\
\hline Pair 21 & X21 & 3,87 &, 782 & Y21 & 3,99 &, 732 & $-2,505$ &, 013 & not fulfilled \\
\hline Pair 22 & X22 & 3,90 &, 832 & Y22 & 4,13 &, 777 & $-4,252$ &, 000 & not fulfilled \\
\hline Pair 23 & X23 & 4,05 &, 791 & Y23 & 4,15 &, 763 & $-1,838$ &, 067 & is in accordance \\
\hline Pair 24 & X24 & 3,74 &, 820 & Y24 & 3,94 &, 815 & $-3,632$ &, 000 & not fulfilled \\
\hline
\end{tabular}

T-test results for the dimensions of service quality between expectation and reality quality in table-4. From the test, tangible and reliability dimension have been accordance with expectations of service quality, where the difference of the average value between the existing services quality with the expectation of service quality, showed no significant difference. While the the average value of responsiveness, assurance and empathy dimensions, the quality of existing services will still not meet the expectations of quality of their services. It is shown that the average value of the expectation of service quality were greater than the value of the quality of existing services and the difference were significant.

TABLE 4. PAIRED SAMPLES STATISTICS TEST FOR DIMENSIONS OF SERVICE QUALITY

\begin{tabular}{|c|c|c|c|c|c|c|c|}
\hline & Real ser & ice quality & Expect & ed quality & & & \\
\hline $\begin{array}{l}\text { Service Quality } \\
\text { Dimensions }\end{array}$ & Mean & $\begin{array}{c}\text { Std. } \\
\text { Deviation }\end{array}$ & Mean & $\begin{array}{c}\text { Std. } \\
\text { Deviation }\end{array}$ & $\mathrm{t}$ & $\begin{array}{l}\text { Sig. (2- } \\
\text { tailed) }\end{array}$ & Meaning \\
\hline Tangible & 18,80 & 3,284 & 18,90 & 3,251 &,- 581 & ,561 & is in accordance \\
\hline Reliability & 19,94 & 3,518 & 20,16 & 3,378 & $-1,231$ & ,219 & is in accordance \\
\hline Responsiveness & 15,78 & 2,623 & 16,26 & 2,779 & $-2,614$ & ,009 & not fulfilled \\
\hline Assurance & 26,76 & 4,853 & 27,91 & 4,823 & $-3,593$ & ,000 & not fulfilled \\
\hline Emphaty & 11,69 & 2,120 & 12,20 & 2,162 & $-3,634$ & ,000 & not fulfilled \\
\hline
\end{tabular}

The results of the analysis of the IPA and the t-test are combined into one table, ie Table-5 and Fig 2. From IPA analysis, there are 6 indicators in A quadrant, means 6 indicators are as main priority; 8 indicators in B quadrant, means the 8 indicators must be maintained; 7 indicators in $\mathrm{C}$ quadrant, means as low priority and 3 indicators exist in $\mathrm{D}$ quadrant, which is an excessive indicators. Based on analysis of IPA and t-test, three indicators that meet the expectations of service quality, two indicators of low priority, 1 indicator excessive. For the 12 indicators that have not met the expectations of service quality, in the main priority are 6 indicators, 2 indicators maintained and 4 indicators as low priority. For 9 indicators as in accordance of service quality expectations, 6 indicators maintained, 1 indicator as low priority and 2 indicators excessive. Indicators in $\mathrm{A}$ and $\mathrm{C}$ quadrant can be considered as an indicator that has not met expectations, ie there are 13 indicators; indicators in $\mathrm{B}$ quadrant are indicator that have been in line with expectations, there were 8 indicators; and indicators in $\mathrm{D}$ quadrant are indicators that already meets the quality expectations, there were 3 indicators. In Table 5, indicators which have not meet expectations labeled as NF (not fulfilled), which according to expectations labeled as AC (accordance), and which already meet the expectations of quality are labeled AM (already meet) for both IPA and interpretation of the results of t-test. Of the two methods are used, there are 17 indicators showed similar results (see Table 5), 7 indicators showed different results. To make a conclusion of seven different indicators, drawn conclusions based on the results of the analysis of the IPA, because the IPA analysis showing the positions and magnitudes of the indicators, whereas the t-test analysis just shows the magnitude, namely the difference between expectations and reality quality. As conclusions, indicators that have not met the expectations there were 13 indicators indicators, which have been as expected there were 8 indicators and which meet the expectations there were 3 indicators. Thus the Bank management should improve the 13 indicators of quality of service, maintain eight indicators that have been as expected and also maintains three indicators that meet quality expectations. 
TABLE 5. IMPORTANT PERFORMANCE ANALYSIS AND T-TEST RESULT

\begin{tabular}{|c|c|c|c|c|c|}
\hline No & Question Items & Quadrant & $\begin{array}{l}\text { Interpretation } \\
\text { IPA }\end{array}$ & $\begin{array}{l}\text { t-test } \\
\text { result }\end{array}$ & Conclusions \\
\hline & Intangible & & & & \\
\hline 1 & $\begin{array}{l}\text { Banks have modern equipment, visually appealing and } \\
\text { comfortable }\end{array}$ & A & $\mathrm{NF}$ & NF & $\mathrm{NF}$ \\
\hline 2 & Bank employees look tidy & $\mathrm{C}$ & $\mathrm{NF}$ & $\mathrm{NF}$ & $\mathrm{NF}$ \\
\hline 3 & $\begin{array}{l}\text { Bank is equipped with a computerized data base } \\
\text { system }\end{array}$ & $\mathrm{D}$ & $\mathrm{AM}$ & $\mathrm{AM}$ & AM \\
\hline 4 & $\begin{array}{l}\text { Bank is equipped with a cooling system (air } \\
\text { conditioner) }\end{array}$ & $\mathrm{C}$ & $\mathrm{NF}$ & $\mathrm{AM}$ & $\mathrm{NF}$ \\
\hline \multirow[t]{2}{*}{5} & Bank service room pleasant & $\mathrm{C}$ & $\mathrm{NF}$ & $\mathrm{AM}$ & $\mathrm{NF}$ \\
\hline & Reliability & & & & \\
\hline 6 & $\begin{array}{l}\text { When the Bank promises to do something by a certain } \\
\text { time, they do }\end{array}$ & $\mathrm{B}$ & $\mathrm{AC}$ & $\mathrm{AC}$ & $\mathrm{AC}$ \\
\hline 7 & $\begin{array}{l}\text { When a visitor has a problem, the Bank showed a } \\
\text { genuine interest to solve }\end{array}$ & $\mathrm{B}$ & $\mathrm{AC}$ & $\mathrm{AC}$ & $\mathrm{AC}$ \\
\hline 8 & Bank doing the right service at the time of the first & $\mathrm{B}$ & $\mathrm{AC}$ & $\mathrm{AC}$ & $\mathrm{AC}$ \\
\hline 9 & Services provided at the when Bank promise to do & $\mathrm{C}$ & NF & NF & $\mathrm{NF}$ \\
\hline \multirow[t]{2}{*}{10} & There is no record of errors during service & $\mathrm{B}$ & $\mathrm{AC}$ & $\mathrm{AC}$ & $\mathrm{AC}$ \\
\hline & Responsiveness & & & & \\
\hline 11 & Employees tell visitors when the service will be & $\mathrm{B}$ & $\mathrm{AC}$ & $\mathrm{NF}$ & $\mathrm{AC}$ \\
\hline 12 & Employees provide prompt service to visitors & A & NF & $\mathrm{NF}$ & $\mathrm{NF}$ \\
\hline 13 & Employees willing to help visitors & $\mathrm{B}$ & $\mathrm{AC}$ & $\mathrm{AC}$ & $\mathrm{AC}$ \\
\hline \multirow[t]{2}{*}{14} & $\begin{array}{l}\text { Employees never reasoned busy to respond to the } \\
\text { demand of visitors }\end{array}$ & $\mathrm{D}$ & $\mathrm{AM}$ & $\mathrm{AC}$ & AM \\
\hline & Assurance & & & & \\
\hline 15 & Employee behavior instill confidence in the visitor & $\mathrm{D}$ & $\mathrm{AM}$ & $\mathrm{AC}$ & $\mathrm{AM}$ \\
\hline 16 & Visitors feel safe and comfortable in the Bank & $\mathrm{A}$ & NF & NF & NF \\
\hline 17 & Employees always polite & $\mathrm{A}$ & $\mathrm{NF}$ & $\mathrm{NF}$ & $\mathrm{NF}$ \\
\hline 18 & $\begin{array}{l}\text { Employees have the knowledge to answer the visitors } \\
\text { questions }\end{array}$ & A & NF & $\mathrm{NF}$ & $\mathrm{NF}$ \\
\hline 19 & Employees serving with friendly & $\mathrm{C}$ & $\mathrm{NF}$ & $\mathrm{AC}$ & $\mathrm{NF}$ \\
\hline 20 & Employees serving satisfactory & $\mathrm{C}$ & $\mathrm{NF}$ & NF & $\mathrm{NF}$ \\
\hline \multirow[t]{2}{*}{21} & Serve with competent employees & A & $\mathrm{NF}$ & NF & NF \\
\hline & Emphaty & & & & \\
\hline 22 & Employees provide individual attention for visitors & $\mathrm{B}$ & $\mathrm{AC}$ & $\mathrm{NF}$ & $\mathrm{AC}$ \\
\hline 23 & Employees understand the specific needs of visitors & $\mathrm{B}$ & $\mathrm{AC}$ & $\mathrm{AC}$ & $\mathrm{AC}$ \\
\hline 24 & Employees serve with heart & $\mathrm{C}$ & NF & NF & $\mathrm{NF}$ \\
\hline
\end{tabular}

$\mathrm{NF}=$ Not fulfilled $\quad \mathrm{AC}=$ Accordance $\quad \mathrm{AM}=$ Already meet 


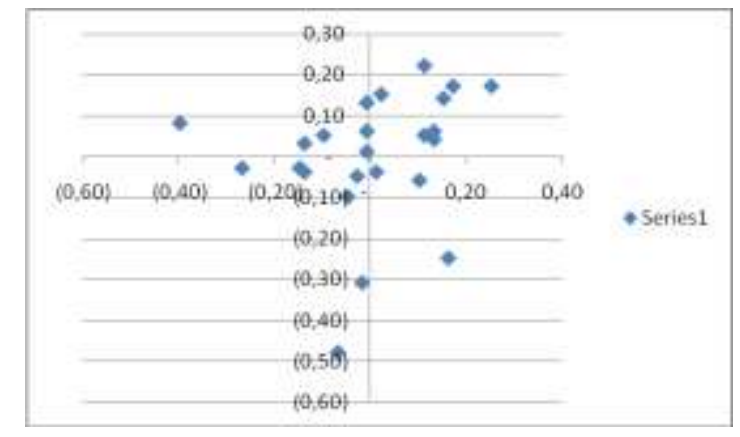

Fig. 2. IPA diagram

\section{CONCLUSIONS}

To face the challenges and opportunities in the business bank for business development, is necessary to evaluate the quality of service periodically. To be in get a strategy to improve the quality of service, SERVQUAL can be used by using t-test and Important Performance analysis. The results of this study showed, from 24 indicators quality of service, there are 12 indicators that have not meet customer expectations, 3 indicators which already meets the expectations and 9 indicators that are in accordance with customer expectations. In addition, from the IPA, there are 6 indicators obtained a high priority, 8 indicators retained, 7 indicators with low priority and 3 indicators that have been excessive. Conclusions from the analysis of the two methods produce indicators that have not met the expectations there are 13 indicators, which have been as expected there were 8 indicators and which have meet the expectations there were 3 indicators. Thus the Bank management should improve the 13 indicators of quality of service, maintain eight indicators that have been as expected and also maintains three indicators that have meet quality expectations.

\section{REFERENCES}

[1] Ravichandran.K, B. Tamil Mani, S. Arun Kumar, S. Prabhakaran, "Influence of Service Quality on Customer Satisfaction Application of Servqual Model," International Journal of Business and Management Vol. 5, No. 4; April 2010. (March 21, 2015). Retrieved from : http://www.google.co.id/url?sa=t\&rct=j\&q=\&esrc=s\&source=web\&cd $=7 \& \mathrm{cad}=\mathrm{rja} \& u a c t=8 \&$ ved=0CE $4 \mathrm{QFjAG} \& u r l=\mathrm{http} \% 3 \mathrm{~A} \% 2 \mathrm{~F} \% 2 \mathrm{Fccsen}$ et.org\%2Fjournal\%2Findex.php \%2Fijbm \%2Farticle\%2Fdownload\%2F 5158\%2F4616\&ei=5HUNVbTMcyouwSzr4H4DQ\&usg=AFQjCNFLo ioz4c8YlhO5TNDgi76Lrl8g\&sig2=uPnfNvZPwylmSbvN7EGmdw\&b $\mathrm{vm}=$ bv. 88528373, d.c2E

[2] Parasuraman, A., Zeithaml, V. A. \& Berry,L,."A conceptual model of service quality and its implications for future research," Journal of Marketing, 49(Fall), 41-50,1985.

[3] Zeithaml VA., Berry, LL., Parasuraman, A, "The Nature and Determinants of Consumer Expectations of Service," Journal of the Academy of Marketing Science, Vol 21, 1993.

[4] Bente Corneliu, "Concept of Service Quality Measurement in Banks," The Faculty of Economics. University of Oradea , 2012. Retrieved from :http://steconomiceuoradea.ro/anale/ volume/2012/n2 /135.pdf
[5] Parasuraman, A., Zeithaml, V. A., \& Berry, L. L,'SERVQUAL: A multiple-item scale for measuring consumer perceptions of service quality," Journal of Retailing, 64, pp.12-40, 1998.

[6] Cronin, J. J. Jr \& Taylor, S. A.,"Measuring service quality: A reexamination and extension," Journal of Marketing, , 405-20, 1992.

[7] Avkiran Necmi K.,"An application reference for data envelopment analysis in branch banking: helping the novice researcher," International Journal of Bank Marketing, Vol. 17 Iss: 5, pp.206 - 220 , 1999.

[8] Martilla, J.A. and James, J.C.,'Importance-Performance Analysis," Journal of Marketing, Vol. 41 (1), pp. 77-79, 1977.

[9] Ennew, C., Reed, G. and Binks, M.R.," Importance-Performance Analysis and the Measurement of Service Quality,"European Journal of Marketing, Vol. 27 (2), pp. 59-61, 1993.

[10] Slack, N.,"The Importance-Performance Matrix as a Determinant of Improvement Priority,"International Journal of Operations \& Production Management. Vol. 14 (5), pp. 59-75, 1994.

[11] Matzler, K., Sauerwein, E. and Heischmidt, K.A. ,'ImportancePerformance Analysis Revisited: The Role of the Factor Structure of Customer Satisfaction," Service Industries Journal, Vol. 23 (2), pp. 112-129,2003.

[12] Huang, Y. and Hsu, J.,"Using Importance-Performance Analysis in Evaluating Taiwan Medium and Long Distance National Highway Passenger Transportation Service Quality,"Journal of American Academy of Business, vol. 8 (2), pp. 98-104.,2006.

[13] Joseph, M., Allbright, D., Stone, G., Sekhon, Y. and Tinson, J.,'Importance-Performance Analysis of UK and US Bank Customer Perceptions of Service Delivery Technologie,"International Journal of Financial Services Management, Vol. 1 (1), pp. 4-15. 2005.

[14] Pike, S.,"The Use of Repertory Grid Analysis and ImportancePerformance Analysis to Identify Determinant Attributes of Universities,"Journal of Marketing for Higher Education, Vol. 14 (2), pp. 1-18, 2004

[15] Janes, P. and Wisnom, M.S.,"The Use of Importance Performance Analysis in the Hospitality Industry: A Comparison Of Practices,"Journal of Quality Assurance in Hospitality \& Tourism, Vol. 4 (1/2), pp. 23-45, 2003.

[16] Fuchs, M. and Weiermair, K.,"New Perspectives of Satisfaction Research in Tourism Destinations," Tourism Review, vol. 58 (3), pp. 614., 2003.

[17] Kitcharoen, K.,"The importance-performance analysis of service quality in administrative departments of private universities in Thailand," ABAC Journal, 24(3), 20-46.,2004.

[18] Abalo, J., Varela, J. and Manzano, V.,'Importance values for Importance-Performance Analysis: A formula for spreading out values derived from preference rankings," Journal of Business Research, 60(2), 115-121., 2007.

[19] Silva, F. and Fernandes, O.,'Using Importance-Performance Analysis in Evaluating of Higher Education: A Case Study. ICEMT 2010 International Conference on Education and Management Technology," IEEE. ISBN: 978-1-4244-8617-5, 121-123, 2010.

[20] Guadagnolo, F.,'The importance-performance analysis: An evaluation and marketing tool,"Journal of Park and Recreation Administration, 3 (2), 13-22,1985.

[21] Bacon, D.,"'Comparison of Approaches to Importance-Performance Analysis,"International Journal of Market Research, 45(1), 55-71, 2003.

[22] Zhang, H. and Chow, I.,"Application of importance-performance model in tour guides' performance: evidence from mainland Chinese outbound visitors in Hong Kong," Tourism Management, 25(1), 81-91, 2004.

[23] Go, F. and Zhang, W.," Applying importance-performance analysis to Beijing as an international meeting destination,"Journal of Travel Research, 35(1), 42-49, 2008.

[24] Krisna Mahendraswara, "Studi Terhadap Kualitas Pelayanan di Hotel Grand Candi Semarang," Skiripsi, 2011 Pada Program Sarjana Fakultas Ekonomi,Universitas Diponegoro.( March 5, 2015). Retrieved from: http://eprints.undip.ac.id/29360/1/ Skripsi002.pdf.

[25] Asif Akhtar \& Dr. Asma Zaheer,"Service Quality Dimensions of Islamic Banks: A Scale Development Approach. Aligarh Muslim University," India. Global Journal of Management and Business 
Research: A Administration and Management.Volume 14 Issue 5 Version 1.0 Year 2014. (March 21,2015). https://globaljournals.org /GJMBR_Volume14/2Service-Quality-Dimensions-of-IslamicBanks. pdf

[26] Herni Justiana Astuti,"Analisa Kepuasan Konsumen (SERVQUAL Model dan Important Performance Analysis Model) (March 21 ,2015).http://download.portalgaruda.org/article.php?article=9606\&val= $\underline{621}$

[27] Aries Susabty, Arief Chandra Putra Buana,”. Atribut-Atribut yang Menjadi Prioritas Untuk Peningkatan Kualitas Layanan," Program Studi Teknik Industri, Universitas Diponegoro-Semarang. Jurnal Teknik Industri, Vol. 12, No. 2, Agustus 2011: 95-103. .(March 5, 2015).Retrieved from: http://citation.itb.ac.id /pdf/JURNAL/ JURNAL\%20TEKNIK\%20INDUSTRI\%20UMM/VOL\%2012\%20No. 2\%202011/555 umm scientific journal.pdf

[28] Jannatul Mawa Nupur,'E-Banking and Customers' Satisfaction in Bangladesh: An Analysis," International Review of Business Research Papers. Volume 6. Number 4. September 2010. Pp. 145 - 156, 2010. (March 21, 2015).Retrieved from :http://irbrp.com/static/ documents/ September/2010/12.\%20Nupur.pdf.

[29] Mohamad Idham Md Razak et al,"Adaptive of SERVQUAL Model in Measuring Customer Satisfaction towards Service Quality Provided by Bank Islam Malaysia Berhad (BIMB) in Malaysia," International Journal of Business and Social Science Vol. 4 No. 10 .Special Issue - August 2013

[30] E. O. Oyetunji , B. Baguri and A. E. Otis,". Comparison of Service Quality ofTwo Commercial Banks in Upper East Region of Ghana.,"Proceedings of the 2014 International Conference on Industrial Engineering and Operations Management . Bali, Indonesia, January 7 - 9, 2014. 2014 (March 21, 2015).Retrieved from: http://iieom.org/ieom2014/pdfs/ 169.pdf.

[31] Aymn Sulieman,"Basic Dimensions of The (SERVQUAL Model) and Its Impact on The Level of Customer Satisfaction: an Emperical Study of The Housing Bank Bank in Karak," Jordan. European Scientific Journal January 2013 edition vol.9, No.1 ISSN: 1857 - 7881 (Print) e ISSN 1857- 743. (March 21,2015). Retrieved from: http://www.google. co.id/url?sa=t\&rct=j\&q=\&esrc=s\&source=web\&cd=8\&cad=rja\&uact $=$ $\underline{8 \& v e d=0 \mathrm{CFYQFjAH} \& u r l=\text { http } \% 3 \mathrm{~A} \% 2 \mathrm{~F} \% 2 \text { Feujournal.org\%2Findex.p }}$ hp\%2Fesj\%2Farticle\%2Fdownload\%2F690\%2F738\&ei=5HUNVbTM cyouwSzr4H4DQ\&usg=AFQjCNERJkdD8MPKjktocnG7RnaStEuAU Q\&sig2=hs2PjQAS4mtCZpAz64gdfA\&bvm=bv.88528373,d.c2E.

[32 ]Ramón A. Carrasco, Francisco Muñoz-Leiva, Juan SánchezFernández,Francisco J. Liébana-Cabanillas.," A model for the integration of e-financial services questionnaires with SERVQUAL scales under fuzzy linguistic modeling.journal homepage: www.elsevier. com/locate/eswa. 2012.(March 21, 2015). Retrieved from: http:/sci2s.ugr.es/ publications/ ficheros/2012-CarrascoESWA.pdf.

[33] Jelena Titko, Natalja Lace,'Service quality Evaluation in Latvian Banking," Riga Technical University, Economics and Management:
2012. 17 (1) ISSN 2029-9338 (ONLINE) ISSN 1822-6515 (CDROM). 2012. (March 21 2015). Retrived from: http://www.ecoman. ktu.lt/index.php/Ekv/article/viewFile /2282/1764

[34] Ghalib Sanjuq.,"The Impact of Service Quality Delivery on Customer Satisfaction in the Banking Sector in Riyadh, Saudi Arabia," www.sciedu.ca/ijba International Journal of Business Administration Vol. 5, No. 4; 2014. (March 21, 2015). Retrieved from: http://sciedu.ca/journal/index.php/ijba/article/viewFile/5121/3011.

[35] Mei Mei Lau, Ronnie Cheung, Aris Y. C. Lam, Yuen Ting Chu.,'Measuring Service Quality in the Banking Industry: A Hong Kong Based Study .Contemporary Management," Research.Pages 263282, Vol. 9, No. 3, September 2013. doi:10.7903/cmr. 11060. 2013 (March 21,2015): Retrieved From: http://www.google.co.id/

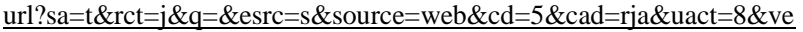
$\mathrm{d}=0 \mathrm{CD} 0 \mathrm{QFjAE} \& u r l=\mathrm{http} \% 3 \mathrm{~A} \% 2 \mathrm{~F} \% 2 \mathrm{Fwww} . \mathrm{cmrjournal}$. org $\% 2 \mathrm{Farticl}$ e\%2Fdownload\%2F11060\%2Fpdf\&ei=5HUNVbMcyouwSzr4H4DQ\& usg=AFQjCNGya1REyo1QVobxIYXDIP4soDiNcw\&sig2=qmqdUqFy m4O4X4rzV6X1Q\&bvm=bv.88528373,d.c2E

[36] Soleyman Iranzadeh,and Farzam Chakherlouy,"Service Quality Dimensions in the Banking Industry and Its Effect on Customer Satisfaction (Case Study) .Department of Management," Tabriz Branch, Islamic Azad University, Tabriz, Iran. 2015, (March 21, 2015). Retrieved from: http://cdn.intechopen.com/pdfs-wm/ 36155.pdf.

[37] Niveen El Saghier, Demyana Nathan,'Service Quality Dimensions and Customers' Satisfactions of Banks in Egypt.,"Proceedings of 20th International Business Research Conference 4 - 5 April 2013, Dubai, UAE, ISBN: 978-1-922069-22-1.2013,(March 21, 2015). Retrieved from: http://www.wbiworldconpro.com/ uploads/dubaiconference2013april/banking/13644628 71 607-Niveen.pdf.

. [38] Najat Abdullrahim,'Service Quality of English Islamic Banks,'Thesis. Business School .Bournemouth University. February 2010 . (March 21 ,2015).Retrieved from : http://eprints.bournemouth.ac.uk/15833/1/ ABDULLRAHIMNajat Ph.D.-2010Service Qualityof English Islamic_Banks.pdf 